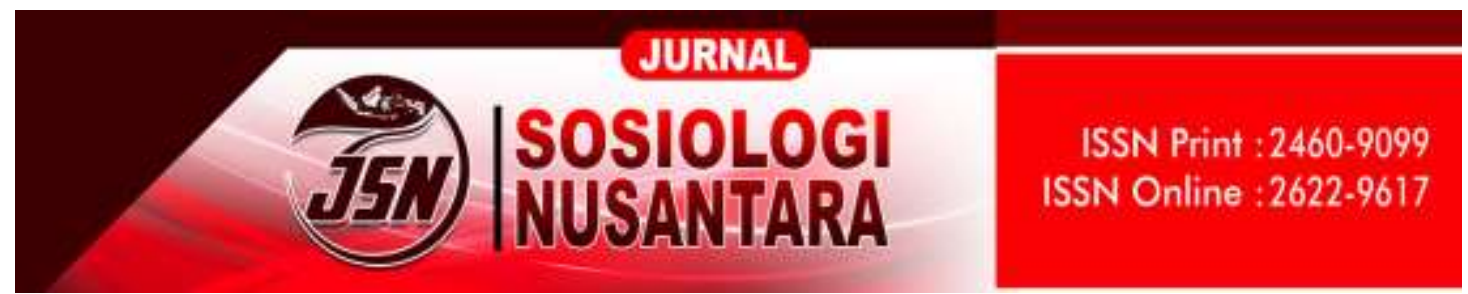

https://ejournal.unib.ac.id/index.php/jsn

DOI ://doi.org/10.33369/jsn.7.1.149-172

\title{
AFIRMASI MODAL SOSIAL \\ UNTUK MENINGKATKAN PERAN PENDIDIKAN MASA DEPAN \\ (Proyeksi Implementasi Pasca Pandemi Covid-19)
}

\author{
AFFIRMING SOCIAL CAPITAL \\ TO ENHANCE THE ROLE OF FUTURE EDUCATION \\ (Of The Post Covid -19 Pandemic Implementations Outlook')
}

\author{
Ina Nurnina \\ nurnina.ina@gmail.com \\ Analis Kebijakan Ahli Muda \\ Kementerian Koordinator Bidang Pembangunanan Manusia dan Kebudayaan \\ Republik Indonesia
}

\begin{abstract}
Abstrak
Dinamika dan perubahan arah pendidikan abad 21 menjadi salah satu fokus pengambilan kebijakan nasional maupun di tingkat global, selain dari penuntasan target Sustainable Development Goals ke 4 di tahun 2025. Pandemi Covid 19 menyebabkan perubahan terjadi semakin cepat. Integrasi teknologi ke dalam kelas menjadi kian krusial dalam kaitannya dengan kebijakan pembelajaran jarak jauh dimasa pandemi, dan arah peta jalan pendidikan masa depan yang akan menjadikan model pembelajaran hybrid (campuran antara tatap muka dan dan kelas virtual) menjadi pilihan terbaik yang diyakini akan mampu mengoptimalkan kemampuan bernalar tingkat tinggi (Higher Order Thinking Skills) dan menjadikan siswa sebagai sentral aktivitas pembelajaran. Hal lainnya adalah perubahan orientasi kemampuan minimum angkatan kerja dalam kurun 5 tahun dari sekarang, yang akan banyak mengalami pergeseran akibat disrupsi teknologi seperti penggunaan artificial intelligence (kecerdasan buatan yang terintegrasi kedalam sistem komputer) dalam proses industri. Penelitian ini bertujuan untuk melakukan observasi mendalam bagaimana suatu modal sosial yang dimiliki bangsa ini mampu dengan cepat dan cakap melakukan transfromasi sektor pendidikan hingga mampu mencetak sumber daya manusia berkualitas yang dapat bersaing secara global. Penelitian berbasis studi literatur dengan pendekatan evaluasi model developmental (DE) ini menyertakan berbagai data berskala nasional maupun internasional terkait kebijakan dan kajian pendidikan. Penelitian ini mengindikasikan urgensi terwujudnya modal sosial yang diperoleh dari komitmen dan kemitraan sejumlah stakeholders pendidikan. Kolaborasi mutual tersebut menjadi kunci
\end{abstract}


percepatan pencapaian target transformasi digital pada aktivitas pembelajaran di Indonesia.

Kata Kunci: Developmental Evaluation, Modal Sosial, Transformasi Pendidikan

\begin{abstract}
The dynamic of $21^{\text {st }}$ Century education is being one of major focus in shaping both national and global policies, likewise in the accomplishment of SDG's number 4 by the year of 2025. The COVID 19 pandemic accelerate changes which already occured years before. Hence, the integration of technology into classroom activities is getting more crucial, along constructing the future of education which assigning hybrid learning model as the most appropriate strategy todays. This also intensify the used of Higher Order Thingking Skills (HOTS) that addressing students as a centre of learning process. Another essential issue is concerning the attainment of competency standards held by our future workforce that needs strategies to prepare them to be proficient in the utilization of automation and artificial intellegence inside industrial activities at least for the next five to ten years. This research aims to comprehensively observe how does the social capital in this country would foster its capacity to develop and to transform the educational sector to prepare the competitive human resources. . This literature-based research is equipped with Developmental Evaluation approach which uses data collection gathered from national and international institutions also other relevant documents. This research indicates the urgency of social capital obtained from both commitment and partnership from educational stakeholders. Thus, mutual cooperation is the key point in carrying out all transformation targets pertaining to the universal digitation in learning in Indonesia.
\end{abstract}

Keywords: Developmental Evaluation, Educational Transformation, Social Capital

\title{
PENDAHULUAN
}

Integrasi teknologi sebagai perangkat penunjang utama pada berbagai aktivitas masyarakat (sosial, ekonomi, politik, budaya) menjadi kian masif dan terakselerasi dengan hadirnya pandemi covid 19 yang telah melanda lebih dari 200 negara termasuk Indonesia sejak awal tahun 2020. Kebijakan karantina wilayah secara menyeluruh (total lockdown) menjadi pilihan terbaik sejumlah negara di Eropa bahkan Asia. Pemerintah Indonesia mengambil jalan tengah dengan melakukan pembatasan sosial berskala besar dengan penekanan pada upaya membatasi mobilisasi masyarakat di luar rumah, kecuali pada sejumlah sektor esensial seperti layanan kesehatan dan kebutuhan logistik masyarakat. Data Dapodik Kemdikbud per April 2020 menyebutkan bahwa lebih dari 68 juta siswa dari 543.630 satuan pendidikan di tanah air (dari jenjang PAUD hingga pendidikan tinggi, termasuk di dalamnya ialah mereka yang belajar dalam bentuk kursus/pelatihan/pendidikan masyarakat) telah melaksanaan pembelajaran jarak 
jauh menggunakan platform digital. Tidak kurang dari 4 juta guru seketika merubah strategi mengajar dengan cara baru yang mungkin tidak pernah dilakukan sebelumnya. Tantangan sekaligus hambatan tentu saja menjadi bagian dari konsekuensi atas kebijakan yang terpaksa diambil pemerintah dalam rangka melindungi keselamatan dan pemenuhan hak hidup sehat seluruh masyarakat dengan menciptakan iklim inovasi dan menyediakan diversifikasi metode pembelajaran dimasa krisis.

Bukan hal yang mudah bagi Indonesia untuk melakukan sebuah transformasi dan akselerasi aktivitas pendidikan. Ketidaksiapan infrastruktur belajar berbasis digital menjadi perhatian utama penyelenggara pemerintahan ditingkat pusat, yang secara konkuren dilakukan bersama dengan pemerintah daerah. Setidaknya masih terdapat 4\% dari total 210.010 satuan pendidikan di tanah air belum teraliri listrik, sementara $9 \%$ dari total 175.730 satuan pendidikan belum terhubung dengan jaringan internet (Kemendikbud, 2017). Hambatan akses pembelajaran digital khususnya terjadi di wilayah tertinggal, terdepan, terluar (3T), serta peserta didik yang berasal dari keluarga dengan kemampuan ekonomi rendah. Revolusi industri 4.0 secara sistemik telah merubah arah pembagunan manusia dalam beberapa tahun terakhir. Kebijakan Pembelajaran Jarak Jauh (PJJ) yang mulai bergulir pada kuartal pertama tahun 2020 memaksa semua pihak yang terlibat dalam proses pendidikan untuk dapat beradaptasi lebih cepat dalam penggunaan perangkat digital sebagai penunjang utama pembelajaran, berikut fitur-fitur pemrograman yang menyertainya. Pelaksanaan pembelajaran jarak jauh juga menjadi sebuah milestone dalam memasuki era baru pendidikan, yang bertujuan untuk membentuk siswa menjadi pembelajar mandiri, yang mampu berkontribusi bagi perubahan baik di komunitas sosial yang lebih luas. OECD Learning Compass 2030 telah menjadi rujukan sistem pendidikan global yang bertujuan untuk peningkatan kompetensi setiap warga negara melalui sektor pendidikan, yang akan berimplikasi langsung pada terciptanya masyarakat yang maju dan sejahtera (OECD, 2019b).

Konsep pembelajaran campuran antara tatap muka dan virtual (Hybrid/blended) menjadi opsi yang diyakini sesuai dengan tantangan pembangunan manusia abad 21, yang mulai dijajaki sebagai konsep pembelajaran masa depan. Hal ini tentu saja menarik, dikarenakan seluruh aspek yang ada didalam proses pendidikan harus mampu memberi daya ungkit bagi peningkatan kualitas kognitif berikut kualitas karakter setiap 
siswa, yang menjadi esensi pembangunan generasi masa depan. Ketersediaan infrastruktur fisik digital, kompetensi mengajar guru dalam konteks pembelajaran berbasis digital, hingga penyiapan konten belajar yang memadai dan ramah anak merupakan sejumlah hal minimum yang harus dipenuhi dalam model atau metode pembelajaran masa depan. Melalui artikel ini, secara khusus dikaji sejauh mana konsep dan teori modal sosial dapat efektif menguatkan seluruh aktivitas pendidikan di era digital dengan menggunakan model evaluasi developmental (Michael Quinn Patton) sebagai dasar dalam melakukan judgement.

\section{METODE PENELITIAN}

Penelitian ini merupakan kajian literatur dengan pendekatan evaluasi, dalam hal ini terhadap kebijakan integrasi digital pada proses pembelajaran yang melibatkan kontribusi lintas sektoral. (Louie, Rhoads, dan Mark 2016) mendefinisikan bahwa bagi pengambil kebijakan, metode evaluasi bak senjata militer dan perlengkapan perang yang harus dipahami dan dimengerti baik oleh komandan militer untuk mendapatkan hasil sesuai dengan target (Leeuw dan Donaldson, 2015). Lebih spesifik Marv Alkin menegaskan bahwa langkah konkrit dalam sebuah evaluasi ialah dengan menggunakan sebuah pendekatan atau model, yang di dalamnya juga memuat statetment atas gambaran secara umum yang didapat atas evaluasi yang telah dilakukan (King, 2006).

Tabel 1 Ruang Lingkup Penelitian dan Definisi Operasional

\section{Ruang Lingkup Penelitian}

\section{Definisi Operasional}

Disepakati sebagai dimensi penting pembangunan masyarakat (Lang dan Hornburg 1998) dan diartikan sebagai sumber (resource) yang timbul dari adanya interaksi (Suharto, 2008)

Modal Sosial yang mencakup saling percaya dan hubungan timbal balik antar individu rangka meningkatkan koordinasi untuk meningkatkan kapasitas kelompok/komunitas (Patuelli dan Savioli, 1920)

Pendidikan Masa

Depan (Proyeksi

Pasca Pandemi

Covid 19)

Pendidikan merupakan indikator kemajuan pada tingkat individu maupun masyarakat yang berkontribusi pada pendapatan dan produktivitas nasional (McGrath, 2010) yang juga berkontribusi pada peningkatan penguasaan teknologi di era industrialisasi (Woolhouse dan Cramphorn, 1999) dan 
penggunaannya di Indonesia masih berada di tahap permulaan (Promise Educ. Indones., 2020)

\section{Sumber: Kompilasi Peneliti, 2021}

Penelitian ini menggunakan data sekunder yang terdiri dari berbagai data skala nasional terkait pembelajaran daring, infrastruktur digital, kompetensi guru, dan berbagai data set penunjang lainnya. Selain dari data-data bersifat deskriptif, penelitian ini juga menyertakan berbagai informasi yang diperoleh dari berbagai literatur (jurnal ilmiah, laporan berskala nasional maupun internasional yang dihimpun dari sejumlah sumber, serta teori-teori yang relefan dengan penelitian ini).

Gambar 1. Tiga Tanya (Tahapan Evaluasi)

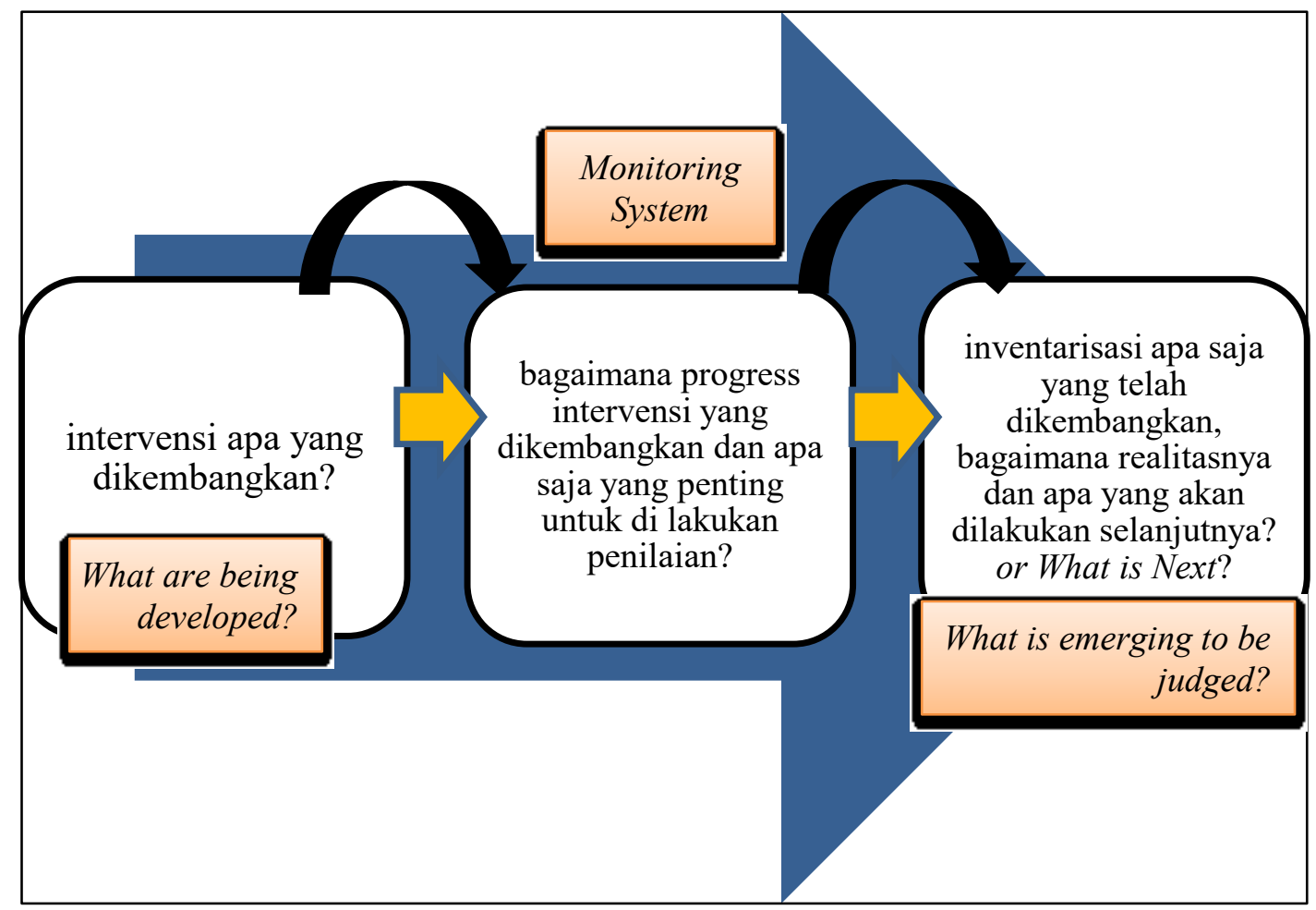

Sumber : Developmental Evaluation (Ricardo, tanpa tahun)

Evaluasi melalui pendekatan Perkembangan atau Developmental Evaluation memiliki kesesuaian fungsi untuk penelitian ini, dikarenakan pembelajaran digital maupun outlook pendidikan masa depan di Indonesia merupakan bentuk inovasi atau hal baru yang berskala besar dan membutuhkan kolaborasi lintas sektoral sebagai bentuk modal sosial dalam implementasi kebijakan nasional di bidang pendidikan. 


\section{PEMBAHASAN}

\section{Modal Sosial dalam Rancangan Kebijakan}

Apa yang dialami indonesia dalam konteks layanan pendidikan dimasa pandemi covid 19 merefleksikan banyak hal yang masih harus dipersiapakan baik dalam hal bagaimana tetap memberikan pemenuhan hak pendidikan bagi seluruh siswa disaat krisis, maupun upaya mempercepat adaptasi tren global yang menginterkoneksikan pendidikan dan kebutuhan pasar kerja di era disrupsi teknologi. OECD (OECD, 2021) dalam rilis hasil risetnya di tahun 2021 menjelaskan bahwa covid 19 telah secara nyata menurunkan angka partisipasi serta meningkatkan angka putus sekolah di Indonesia. Perbedaan hasil capaian belajar antara wilayah-wilayah dengan kemampuan digitalisasi memadai dengan berbagai wilayah dengan kondisi minim bahkan ketiadaan akses listrik dan jaringan internet menjadi gambaran bahwa butuh upaya lebih untuk mewujudkan universal digitation in learning. Dalam laporan tersebut, OECD merekomendasikan peningkatan efisiensi belanja negara dan penciptaan iklim investasi untuk mendukung sektor pendidikan khususnya bagi perluasan akses digitalisasi pendidikan, memperkuat pendidikan vokasi, maupun upskill dan reskill pada tenaga kerja dengan memperkuat peran dan kerjasama stakeholders (public privat partnership), serta peningkatan akses dan cakupan pelaksaan pendidikan jenjang pra sekolah (early childhood education). Ketiga hal tersebut diyakini secara berkesinambungan akan meningkatkan kesetaraan dan kualitas pendidikan di Indonesia.

Pada kajian ini, penulis juga menyoroti beberapa poin penting yang disampaikan The World Bank (World Bank 2020) yang diantaranya terkait arah kebijakan kementerian pendidikan dan kebudayaan dalam mengupayakan transformasi sistem pendidikan melalui penguatan teknologi dalam pembelajaran. Kajian tersebut setidaknya memberikan infromasi bahwa pengembangan ekosistem dan layanan pendidikan termasuk konten belajar berbasis digital di Indonesia saat ini masih terfokus untuk jenjang pendidikan menengah dan tinggi, namun masih sedikit sekali untuk jenjang pendidikan dasar dan vokasi. Temuan lainnya adalah bahwa, produk layanan pendidikan berbasis teknologi saat ini masih belum banyak dirasakan oleh peserta didik dengan latar belakang keluarga berpenghasilan rendah, maupun mereka yang jauh dari perkotaan. Sejumlah hambatan lain yang masih dirasakan dalam pengembangan 
pendidikan berbasis teknologi di Indonesia ialah keterbatasan pendanaan, kurangnya tenaga profesional untuk menciptakan dan mengembangkan produk atau platform belajar dan bahan ajar, lemahnya infrastruktur digital, serta overlaping peran dan fungsi antara pemerintah pusat dan daerah dalam implementasi sistem pendidikan berbasis teknologi.

Secara Terminologi, (Fathy, 2019a) mendefiniskan modal sosial sebagai kemampuan para aktor untuk menjamin manfaat dengan bertumpu pada keanggotaan dalam jejaring sosial dan struktur sosial lain (Fathy, 2019b) modal sosial yang dimiliki seorang anggota dari suatu kelompok tergantung dari kuantitas maupun kualitas hubungan yang dapat diciptakan, serta seberapa besar modal ekonomi, budaya dan sosial yang dimiliki oleh setiap orang yang ada di jejaring hubungannya (Syahra 2003). Modal sosial dijelaskan (Suharto 2008) dilatarbelakangi pemikiran bahwa anggota masyarakat tidak mungkin secara individu mengatasi masalah yang dihadapi, dimana diperlukan kebersamaan yang baik antara seluruh masyarakat yang berkepentingan untuk mengatasinya (Fathy 2019a). Sehingga keberadaan kelompok masyarakat dengan ragam keahlian dan fungsi sosial yang majemuk dan unik dapat secara konkrit berkontribusi dalam implementasi sejumlah rancangan kebijakan yang disusun pemerintah, dengan mengedepankan kesamaan visi dan relasi yang harmonis didalamnya.

Sehingga dalam konteks pelaksanaan tata pemerintahan, modal sosial ialah capaian atas jalinan atau hubungan yang mutual dan sinergis antar aktor atau pemangku kepentingan dalam mencapai sebuah tujuan yang telah disepakati, dimana masingmasing pihak memiliki kapabilitas yang mumpuni dan khusus atau spesifik. Untuk dapat memahami apa yang dapat dilakukan dalam praksis modal sosial sebagai dasar pembuatan kebijakan publik, sejumlah upaya yang dapat dilakukan ialah (Lang dan Hornburg 1998): 1) standarisasi langkah-langkah yang melihat capaian modal sosial; 2) merumuskan dan menetapkan sejumlah formula atau bentuk-bentuk modal sosial yang dapat dilakukan; 3) melakukan kajian dimana titik efektifitas serta kelemahan dalam keterikatan sosial yang ada; 4) menentukan bagaimana infrastruktur sipil/pemerintah dapat menjembatani berbagai komunitas kelompok di masyarakat; 5) melakukan evaluasi kepraktisan dalam membangun modal sosial dan infrastuktur sipil; serta 6) mengidentifikasi pelaku kunci untuk dilibatkan dalam membangun modal sosial. 
Hal lain yang menjadi esensi dari pentingnya modal sosial sebagai jalan mewujudkan perubahan yang lebih baik di masyarakat ialah sebagaimana dijelaskan (Syahra 2003) bahwa jika modal sosial hanya dilihat sebagai sumber daya kelompok, maka akan menghasilkan sebuah kesulitan dikarenakan tidak semua di dalam sebuah kelompok memiliki kesamaan tipikal dan akses, sehingga sangat penting modal sosial dipahami baik sebagai sebuah kebutuhan bagi sektor swasta maupun sektor publik/sipil (Boeck dan Fleming, 2005).

Gambar 2. Ilustrasi capaian pengembangan model social capital, dengan menggabungkan seluruh aspek fundamental yang menjadi kesepakatan

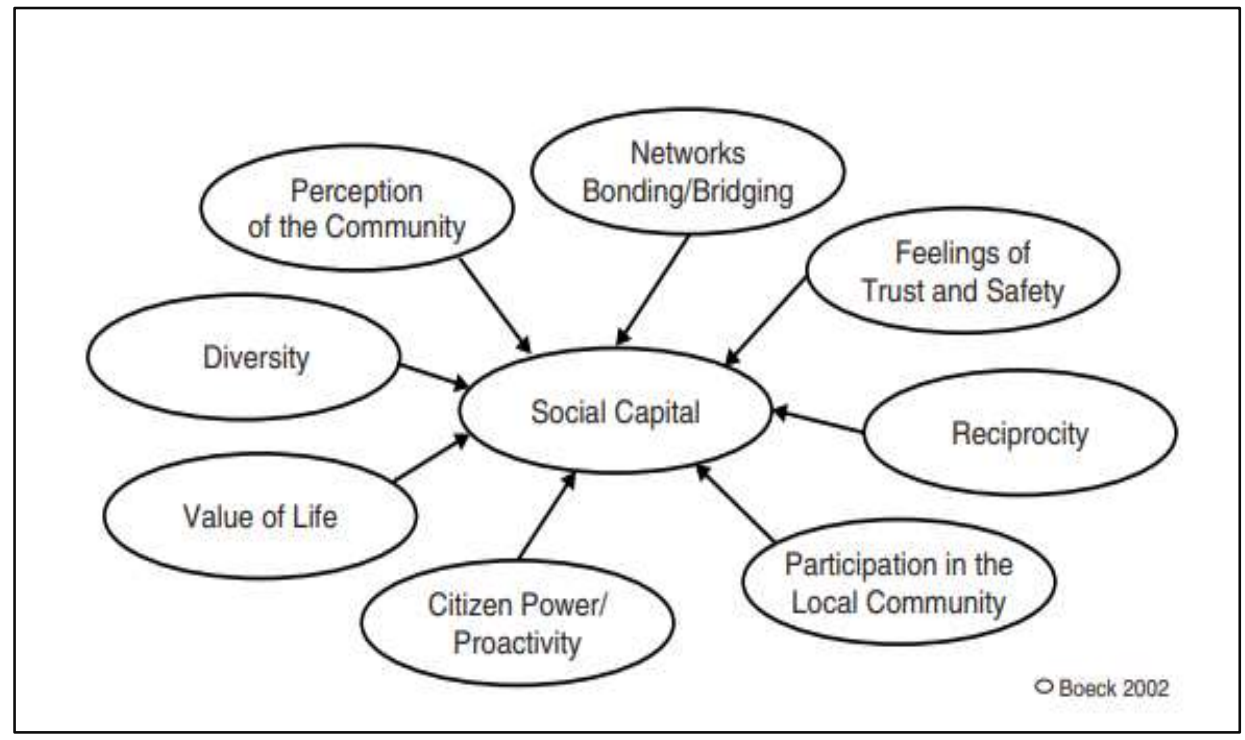

Sumber: Boeck dan Fleming, 2005

Kompleksitas permasalahan yang dihadapi Indonesia dalam pembangunan ekosistem pendidikan berbasis digital akan sulit terselesaikan jika hanya menjadi ranah tugas pokok dan fungsi pemerintah ditingkat pusat. Keterbatasan kemampuan finansial dalam pemerataan dan penyiapan akses infrastruktur, tumpang tindih kebijakan pemerintah pusat dan daerah, serta keterbatasan SDM yang memiliki kecakapan dalam penyiapan konten pembelajaran digital dan pemberian training digital pedagogic teaching kepada seluruh guru, menjadi beberapa masalah pokok yang perlu menjadi concern seluruh pemangku kepentingan. Poin penting lainnya tentu saja bagaimana harmonisasi dan pembagian peran antara pemerintah dan sektor swasta untuk mencapai sebuah kesamaan visi dan dalam memformulasikan rancangan implementasi yang konkrit dan adaptif.. 
Sebagai referensi lainnya, penulis telah melakukan meta analisis dari tiga publikasi ilmiah yang memfokuskan kajiannya pada keberfungsian modal sosial dalam meningkatkan kualitas hidup masyarakat. Jumirah dan Heni Wahyuni dalam risetnya di tahun 2018 terkait analisis dampak atau pengaruh modal sosial terhadap tingkat kesejahteraan di Indonesia, menggunakan analisis data cross sectional dengan model grootaert menunjukan signifikansi pengaruh modal sosial terhadap capaian kesejahteraan masyarakat, dimana trust atau kepercayaan dapat menurunkan biaya transaksisonal pada proses negosiasi (Jumirah, 2018). Hasil riset pada dimensi modal sosial lainnya yaitu social networking, modal sosial secara signifikan berpengaruh positif terhadap tingkat pendapatan keluarga, dan menyiratkan bahwa partisipasi masyarakat dalam aktifitas sosial atau komunitas, dapat meningkatkan kesejahteraan atau pendapatan.

Kajian selanjutnya ialah keterkaitan antara pendidikan dan modal sosial, yang diangkat oleh Sadegh Bafandeh di tahun 2011 yang bertujuan untuk melihat lebih dekat peran strategis dan kontribusi modal sosial dalam mencapai tujuan berbagai kebijakan pemerintah, salah satunya dalam hal pendidikan. Kajian tersebut menunjukkan hasil bahwa pendidikan secara signifikan berpengaruh terhadap kualitas modal sosial di suatu negara. Hal lainnya yang diungkap dalam riset tersebut ialah bahwa modal sosial menjadi sarana menyatukan persepsi pihak-pihak terkait pentingnya mempertimbangkan asset non material dalam kebijakan sosial (Imandoust, 2011)

Kajian ketiga coba digali oleh Muhammad Abrar, Farheen Akram dan Muhammad Adeel (2015) berjudul "The Impact of Social Capital on Educational Attainment: evidence from rural areas of Pakistan" yang salah satunya melihat aspek pendidikan dan latar belakang keluarga. Hasil studi tersebut menunjukan signifikansi bahwa pendapatan rumah tangga berpengaruh langsung pada pencapaian pendidikan siswa, dikarenakan semakin sejahtera keluarga, orang tua dapat semakin banyak memberikan fasilitas penunjang belajar. Fakta lainnya ialah angka partisipasi dan capaian prestasi di sekolah ditunjukkan oleh mayoritas anak-anak yang memiliki kepala keluarga laki-laki. Riset ini sekaligus menggambarkan bahwa anak-anak dengan figur orang tua yang utuh memiliki kecenderungan lebih semangat dan fokus dalam belajar dan bersekolah (Abrar ul Haq, Akram, dan Farooq, 2015) 
Dari ketiga kajian diatas, dapat disimpulkan bahwa modal sosial juga berfungsi sebagai katalisator sebuah perubahan atau jalan menuju target yang ingin dicapai, yang di dalamnya membutuhkan sebuah proses dan komitmen dari seluruh stakeholders. Siapapun berpotensi untuk berkolaborasi untuk membawa perubahan baik, dimana dalam lingkup sederhana dilakukan oleh orang tua. Orang tua memiliki peran penting dalam membentuk kepribadian siswa sejak usia dini, dan terus mendampingi tumbuh kembang anak-anak mereka. Untuk itu, orang tua berperan penting dalam sebuah modal sosial yang bertujuan untuk peningkatan kualitas manusia dalam perspektif pendidikan.

Peneliti meyakini, bahwa kajian tentang peran strategis modal sosial dalam pembangunan dibidang pendidikan menjadi sangat essensial, khususnya dalam rangka mempersiapkan generasi mendatang sebagai modal manusia yang mampu menjawab tantangan global, serta berkontribusi positif pada pendapatan nasional (human as a capital). Transformasi pendidikan berbasis digital merupakan sebuah keniscayaan sekaligus hal tantangan bagi siswa, sekolah, guru-guru, orang tua, bahkan bagi pemerintah maupun dunia usaha, yang seluruhnya membutuhkan sinergi dan pembagian peran untuk menciptakan ekosistem pendidikan yang kondusif dan sesuai dengan kebutuhan peserta didik atau calon angkatan kerja masa depan.

\section{Kondisi Aktual Pendidikan Nasional}

Pembangunan manusia melalui sektor pendidikan dalam beberapa tahun terakhir berorientasi untuk meningkatkan kemampuan digital peserta didik sehingga lebih dapat dengan cepat menyesuaikan diri dengan kebutuhan dunia kerja di era disrupsi teknologi seperti halnya integrasi Artificial Intelligence (AI) dan Cloud Computing pada aktivitas industri. Pembahasan di tingkat internasional menyepakati bahwa masa depan ialah tentang mengkolaborasikan AI dari komputasi dengan penguasaan aspek kognitif, sosial dan emosional manusia, sehingga yang utama adalah meningkatkan kualitas dan kompetensi manusia sebagai pengguna AI atau robotik (OECD, 2019a). Hal tersebut juga menyiratkan bahwa teknologi memberikan kontribusi dalam fungsi pendidikan dengan memberikan keluasan akses informasi yang membantu siswa memahami isi materi ajar, serta peningkatan penguasaan STEM (Science, Technology, Engineering 
and Mathematics) (Schleicher 2019) sebagai bagian dari penyiapan sumber daya manusia yang berdaya saing.

Tahun 2018 menjadi awal perluasan indikator kompetensi siswa usia 15 tahun pada assessment yang dilakukan Program For International Students (PISA), yaitu dengan menambahkan kompetensi global, kemampuan berfikir kreatif dan pembelajaran di era digital (OECD, 2020). Hasil Evaluasi dan capaian PISA tahun 2018 peserta didik yang berasal dari Indonesia menunjukkan bahwa terjadi penurunan pada ketiga indeks yang diukur tersebut, baik pada kemampuan membaca, matematika dan ilmu pengetahuan yang diujikan kepada 12.098 peserta didik yang berasal dari 399 satuan pendidikan (Kemenko PMK, 2020). Lebih lanjut bahwa sejumlah kondisi sertaan hasil capaian PISA tahun 2018 dapat dijelaskan sebagai adaptasi transformasi pembelajaran di tanah air yang mengarah pada penguasaan dan penggunaan perangkat TIK didalam aktivitas pembelajaran. Konsep assessment PISA menggunakan multiteks berbasis komputer, dimana dibutuhkan kecakapan siswa dalam hal menangkap makna yang tersaji di dalam paragraf, keluasan kosakata, kecepatan mengemas tautan antar teks, antara teks dengan grafik, antar teks dan simbol, namun pula mampu tetap terampil mengerakkan pandangan dan cekatan di atas keyboard, serta mempertahankan ingatan pada bagian teks yang telah dilewati, dengan kata lain membutuhkan keterampilan berpikir tingkat tinggi (Higher Order Thinking Skills).

Hal evaluasi yang dilakukan atas capaian PISA tahun 2018 menunjukkan bahwa kompetensi siswa yang menggunakan perangkat TIK dalam pembelajaran sehari-hari di kelas, memiliki skor yang lebih tinggi dibandingkan mereka dengan yang tidak. Dengan gambaran tersebut, diharapkan guru-guru mulai menjadikan TIK sebagai bagian penting dalam proses belajar. Sehingga Kementerian Pendidikan dan Kebudayaan merancang sejumlah perubahan yang dapat meningkatkan kualitas capaian pembelajaran yaitu (Fadhil et al., 2018): 1) Menggunakan perangkat Teknologi Informasi dan Komunikasi (TIK); 2) melibatkan siswa dalam membaca; 3) meningkatkan strategi membaca nyaring; 4) merangkum bukan menyalin; 5) memperkaya jenis bacaan siswa; dan 6) menumbuhkan kebiasaan membaca saat luang.

Disisi lain, transformasi pembelajaran sebagai dampak langsung pandemi covid 19 telah mentransformasi wajah pendidikan tanah air. Kebijakan belajar dari rumah menggunakan diversifikasi platform belajar memberikan dampak positif pada 
percepatan penguasaan kompetensi TIK para siswa dan guru, sekaligus tambahan pekerjaan rumah bagi sistem pendidikan di tanah air. Aktivitas pendidikan dimasa pandemi menjadi potret bahwa setiap negara harus memiliki sense of crisis atau mitigasi pada kondisi-kondisi darurat. Pandemi telah membawa Indonesia kepada lompatan tinggi digitalisasi pendidikan yang sejalan dengan kebutuhan dunia industri 4.0. Tantangan tersebut tentu saja harus disertai dengan kesiapan stakeholders untuk pula melakukan revitalisasi dan re-desain program dan anggaran operasional. Katakan misalnya dari sisi alokasi anggaran, sejumlah institusi di tingkat pusat telah merelokasi atau mentargetkan pembangunan infrastruktur (listrik dan jaringan) di desa dan daerah 3T dengan tujuan tercapainya prasyarat pelaksanaan universal digitation in learning. Tidak jauh berbeda dari sisi alokasi belanja pemerintah pusat, kebijakan penggunaan technological devices sejatinya ditunjang pula dengan alokasi anggaran daerah untuk penguatan sarana-prasarana TIK di setiap satuan pendidikan, peningkatan kompetensi digital teaching tenaga pendidik dan penyiapan modul-modul pendampingan (bagi orang tua). Esensi berbagi peran dan kewenangan inilah yang diharapkan dapat mempercepat penyelesaian target prioritas penyelenggaran pendidikan dimasa krisis, maupun sebagai modal pendidikan masa depan.

Kesiapan infrastruktur telekomunikasi menjadi prioritas dalam mewujudkan konsep pembelajaran berbasis digital. Perbedaan kualitas infrastruktur telekomunikasi termasuk jaringan internet berpotensi mempertajam disparitas capaian pembelajaran secara nasional. Kementerian Komunikasi dan Informatika di tahun 2020 menegaskan bahwa pekerjaan rumah terbanyak untuk mengalirkan sinyal internet berada di wilayah Papua, dimana baru 47\% yang aksesibel terhadap sinyal telekomunikasi dan jaringan internet (Andini, 2020). Lebih spesifik, gambaran infrastruktur dasar pelaksanaan pembelajaran daring di masa pandemi menunjukkan masih terdapat lebih dari 20 ribu satuan pendidikan (dikdasmen/SLB/madrasah) yang masih menghadapi keterbatasan akses listrik, dan lebih dari 56 ribu satuan pendidikan belum terkoneksi jaringan internet. Kondisi ini menjadikan pjj atau penggunaan perangkat digital dalam pembelajaran menjadi sebuah dilema tersendiri, dimana ketersediaan sarana prasarana yang tidak merata pada satuan pendidikan maupun yang dimiliki siswa justru akan menyebabkan ketimpangan kualitas pendidikan semakin tajam dan hak memperoleh pendidikan yang layak tidak dimiliki bagi mereka yang minim akses. 
Ketersediaan perangkat TIK bukan satu-satunya prioritas stakeholders pendidikan dalam transformasi pembelajaran, titik krusial selanjutnya ialah affordability, dalam hal ini adalah daya beli serta kompetensi dasar dalam melakukan digital literacy juga digital citizenship baik bagi guru, siswa serta orang tua. Program bantuan yang telah bergulir seperti pemberian Kartu Indonesia Pintar (KIP) bagi seluruh peserta didik hingga mahasiswa dengan KIP kuliah, relaksasi penggunaan Bantuan Operasional Sekolah (BOS) dan Bantuan Operasional Pendidikan (BOP) menjadi beberapa instrumen pemerintah dalam menunjang transformasi pendidikan di tanah air, khusususnya dimasa pandemi.

Gambar 3 : Jangkauan dan penggunaan internet

Per keluarga dalam kurun tiga bulan terakhir

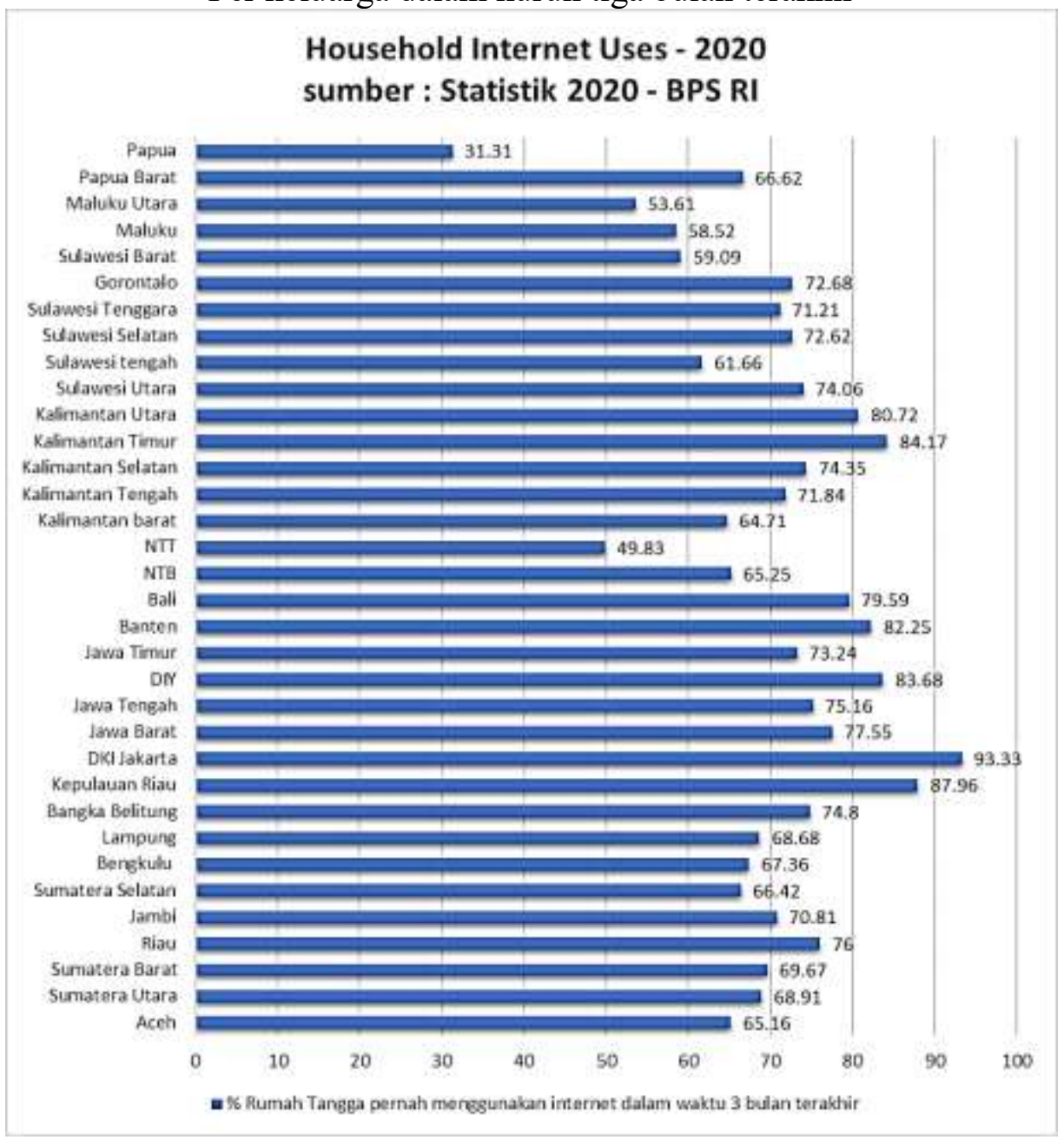

Sumber: Statistik Tahun 2020, BPS RI

Peningkatan mutu pendidikan idealnya sejalan dengan sejauh mana sumber daya pendukung utama dalam hal ini tenaga pendidik mampu menjadi katalisator yang 
mumpuni. Data statistik menunjukkan saat ini terdapat lebih dari 2,9 juta guru (jenjang pendidikan dasar dan menengah termasuk SMK) yang sejumlah 845.171 (29\%) merupakan tenaga didik yang berusia 50 - diatas 65 tahun (Direktorat Jendral GTK kemdikbud, 2020) dengan prosentase guru layak mengajar (mengacu pada peraturan Mendiknas No 16 tahun 2007) mencapai 91,76\% untuk tahun ajaran 2019/2020 (Kecerdasan dan Ikep n.d.) dan prosentase guru layak mengajar pada seluruh jenjang pendidikan madrasah sebesar 90\% (Renstra Kemenag, 2020) dari total 383.426 guru seluruh Indonesia (Direktorat jendral Pendis, 2020), sehingga masih menyisakan sekitar $10 \%$ tenaga pendidik untuk diperkuat pada aspek kompetensi mengajar, yang juga harus mencakup kemampuan digital (komputasi dan pedagogik).

Pada kondisi ini, kolaborasi sektor swasta dengan pemerintah dalam penyiapan konten-konten belajar yang terstandard dan mudah dioperasikan, serta dipahami oleh guru-guru menjadi sangat strategis untuk diupayakan. Sebagaimana hasil kajian world bank di tahun 2021 yang menunjukkan bahwa konten digital yang ada di Indonesia baru mengakomodir kebutuhan jenjang pendidikan menengah dan tinggi, namun masih sangat minim untuk jenjang pendidikan dasar dan vokasi, serta masih relatif mahalnya platform belajar digital yang sulit dijangkau peserta didik dari keluarga ekonomi lemah (World Bank, 2020), bahkan pula dirasa memberatkan sebagian guru dengan honor minim.

Gambar 4: Akses Listrik dan Internet Satuan Pendidikan

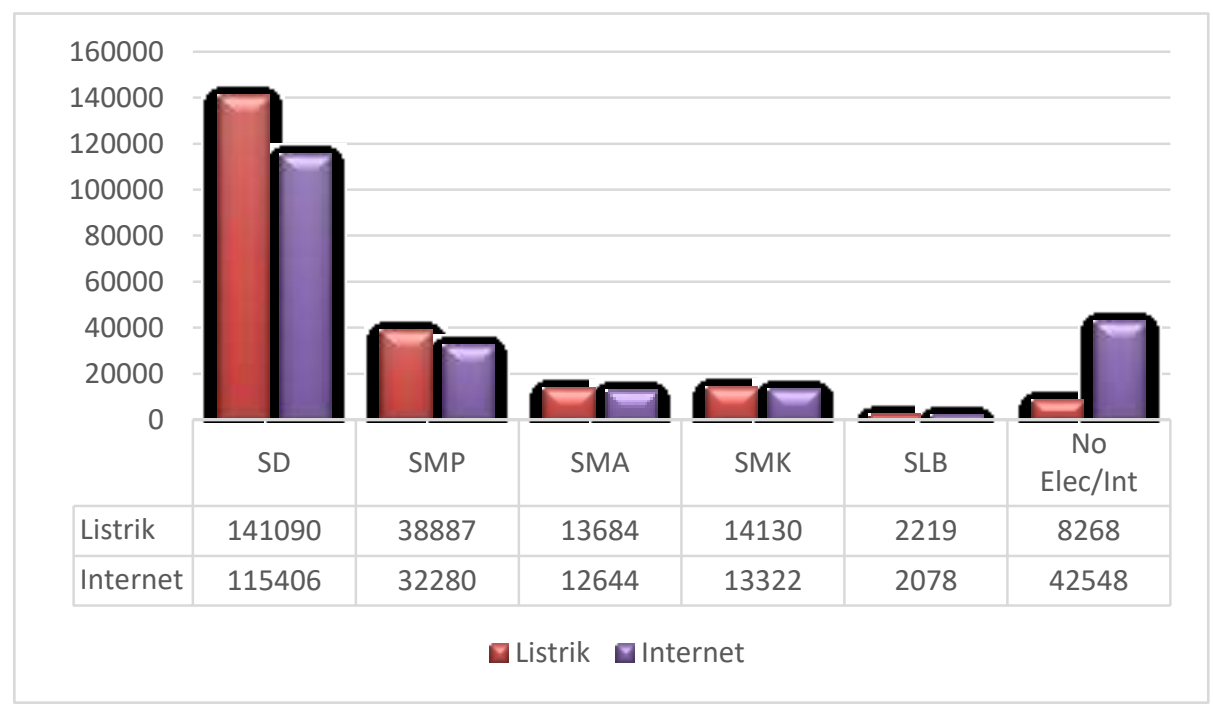

Sumber : Dapodik Kemdikbud, Tahun 2020 
Gambar 5. Akses Listrik dan Internet di Lingkungan Madrasah

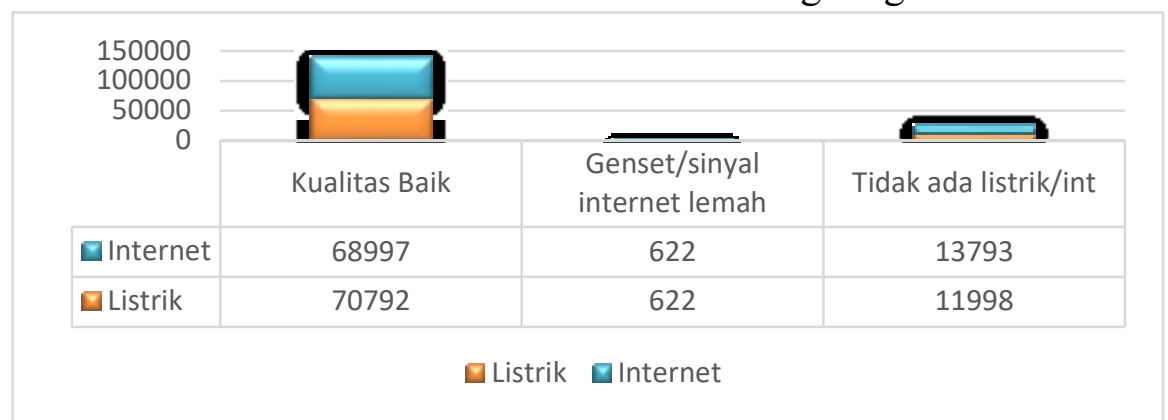

Sumber: Direktorat KKSK Madrasah Kementerian Agama Tahun 2020

Untuk jenjang pendidikan tinggi, kebijakan pemerintah lainnya ialah kemitraan dengan dunia usaha dan industri (DU/DI). Digital kompetensi dan inovasi merupakan dua hal yang dipersiapakan dengan matang di perguruan tinggi, salah satunya dengan penyusunan kurikulum era industri 4.0 sebagaimana diatur dalam Permendikbud Nomor 3 tahun 2020 pasal 1 yang menekankan pada pemutakhiran kurikulum agar sesuai dengan perkembangan Ilmu Pengetahuan, Teknologi dan Seni atau IPTEKS (Dikti, 2020) dengan dua fokus utama di tahun 2020 - 2035 yaitu mempersiapkan lulusan yang langsung dapat terserap di dunia kerja dan menyiapkan minimal 85\% pengajar yang memiliki pengalaman atau sertifikasi industri (Rakyat Merdeka, 2020). Sekali lagi upaya tersebut ialah dalam rangka mempersiapkan lulusan perguruan tinggi siap terserap di dunia usaha dan industri baik lokal maupun global.

\section{Developmental Evaluation (DE) Pada Peran Modal Sosial Dalam Rangka Memperkuat Transformasi Pendidikan di Indonesia}

Evaluasi dengan pendekatan Developmental yang digagas dan dikembangkan oleh Michel Quin Patton (2009) menekankan pada kebermanfaatan inovasi dan berbagai perubahan yang terjadi untuk merubah sebuah kondisi menjadi semakin baik dengan interkorelasi antara 2 aspek utama yaitu "identifying proven principles for adaptive management versus identifying and disseminating proven models" (Patton, 1994). Hal tersebut menegaskan bahwa sebuah evaluasi tidak semata-mata menghasilkan sesuatu yang statis, namun hasil atas evaluasi dapat terus berkembang sejalan dengan berbagai dinamika internal maupun eksternal dari sebuah program maupun kebijakan. Patton juga menjelaskan bahwa Developmental Evaluation dapat menggunakan beragam metode evaluasi maupun assessment yang sangat pula memungkinkan untuk dilakukan metode quasi experiment (Guijt et al. 2012). 
Dalam konsep yang dikembangkan melalui Devepomental Evaluation (DE), Patton menegaskan bahwa "Developmental Evaluation" tidaklah sama dengan “Development Evaluation”, dimana Developmental Evaluation (Evaluasi Perkembangan) dapat digunakan untuk mengevaluasi sebuah pembangunan yang berkembang dinamis dan kompleks (Guijt et al. 2012). Developmental Evaluation memiliki kesesuaian untuk digunakan dalam sejumlah kondisi seperti dampak atau kebermanfaatan sebuah inovasi, desain ulang program yang radikal/tiba-tiba, berbagai masalah yang kompleks hingga sebuah kondisi krisis yang terjadi (Koleros et al. 2016). Secara umum, Developmental Evaluation berfungsi untuk memonitor dan melihat progress 1) sebuah perubahan hubungan antar komponen pada sebuah sistem, 2) kesesuaian boudaries / batas-batas yang digunakan pada tiap komponen, 3) serta berbagai perbedaan perspektif tentang perubahan apa saja yang terjadi dengan adanya sebuah intervensi (DiStefano dan Morgan, 2010). Konstalasi dalam gambar 6 mengelaborasi kekuatan modal sosial yang dimiliki masing-masing stakeholders dalam menyiapkan ekosistem berbasis digital yang sejalan dengan tren yang dibutukan dunia kerja dalam kurun waktu 10 sampai 25 tahun mendatang. Penelitian ini mengidentifikasi setidaknya terdapat 5 komponen strategis yang dapat diupayakan pemerintah bersama-sama dengan sektor industri/private sector yaitu: 1) Infrastruktur; 2) Digital Pedagogic Teaching ; 3) Pengembangan konten/bahan ajar; 4) Relevansi kurikulum pendidikan tinggi dalam menghasilkan lulusan yang berdaya saing dalam bursa kerja global; 5) Kemitraan dengan Dunia Usaha dan Industri (DU/DI).

Pada konstalasi yang dikembangkan melalui kajian ini, komponen pertama memfokuskan pada cakupan infrastruktur fisik dalam kerangka pemenuhan akses pembelajaran berbasis digital (Universal Digitation in Learning) yang tentu saja bukan menjadi hal mudah bagi sebuah negara berbentuk kepulauan seperti Indonesia. Sejumlah strategi nasional yang telah masuk kedalam APBN tahun 2021 diantaranya berupa pembangunan base transceiver station (BTS) di 5.053 desa di wilayah $3 \mathrm{~T}$, pembangunan pusat data nasional serta bantuan perangkat keras (gawai dan laptop), pemetaan blank spots atau inventarisasi satuan pendidikan dengan keterbatasan akses listrik dan jaringan internet, hingga alokasi APBN Rp.29,6 Trilyun yang tersebar pada anggaran lintas kementerian dan transfer ke daerah dan dana desa (TKDD) (Anon, 2021). Perubahan skema prioritas penggunaan Dana Alokasi Khusus (DAK) bidang 
pendidikan yang diantaranya mengkhususkan penguatan infrastruktur TIK satuan pendidikan di setiap daerah di seluruh jenjang pendidikan formal hingga Sanggar Kegiatan Belajar (SKB) (Peraturan Presiden Republik Indonesia, 2019) memberikan angin segar bagi kekuatan lintas sektoral termasuk antara pemangku kebijakan tingkat pusat dan daerah untuk memanfaatkan peluang tersebut, yaitu dalam rangka mengoptimalkan pembangunan infrastruktur TIK termasuk konektivitas jaringan internet di sejumlah wilayah yang masih sangat tertinggal, seperti Papua dan berbagai wilayah Indonesia bagian timur lainnya.

Kesiapan ekosistem menjadi fokus arah kebijakan pembangunan sektor pendidikan selanjutnya, dimana salah satunya bertumpu pada peningkatan kualitas atau kompetensi tenaga pendidik dalam beradaptasi dengan konsep pembelajaran berbasis digital atau digital pedagogic teaching yang menekankan pada bagaimana guru dapat menyesuaikan dengan kecepatan peserta didik beradaptasi dengan teknologi, atau upaya mengintegrasikan keterampilan komputasi kedalam kelas (Howell n.d.) yang sejalan dengan konsep pembelajaran abad 21 dan berorientasi pada inquiry process dan project based learning (Sailin dan Mahmor, 2018). Sehingga optimalisasi fungsi P4TK maupun berbagai komunitas bidang ajar seperti halnya MGMP dalam menghasilkan inovasi dan saling berbagi praktik baik antar tenaga pendidik menjadi sangat strategis.

Gambar 6. Identifikasi Intervensi Penguatan Fungsi Pendidikan melalui Integrasi Teknologi dikembangan oleh peneliti, yang diadaptasi dari Konsep Developmental Evaluation RBM-UNFPA (United Nation Population Fund, 2019)

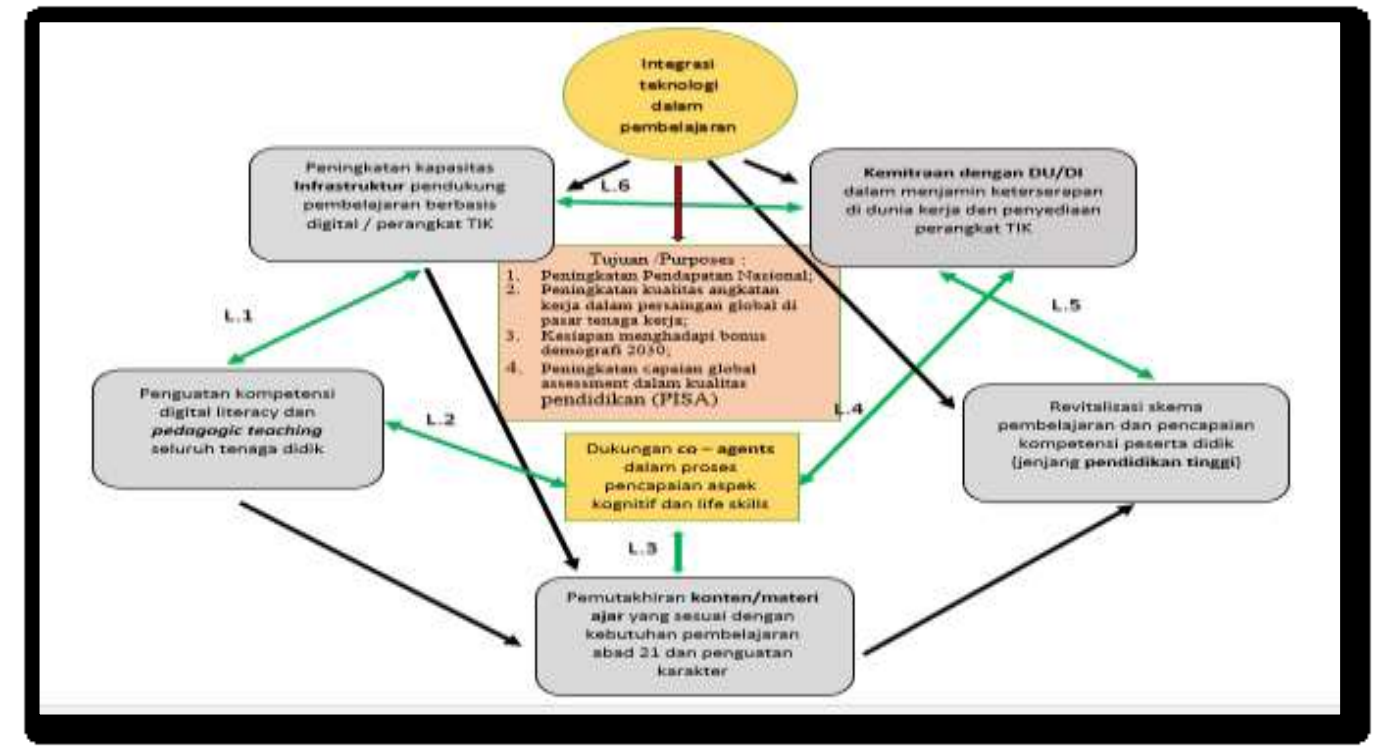

Sumber: Rancangan Peneliti, Tahun 2021 
Kementerian Agama melalui pengembangan Program Madrasah Digital telah menyusun panduan operasional penyelenggaraan kegiatan pembelajaran bagi guru-guru dan tata kelola madrasah dalam kerangka implementasi injeksi computational thinking, yang sangat relevan untuk didukung penuh baik dalam hal penguatan tata kelola hingga assessment atas pengembangan berbagai inovasi sebagai milestone transformasi pendidikan.

Tujuan pendidikan diantaranya tentu saja untuk menghasilkan para lulusan yang berkualitas, kompetitif secara global serta dapat memenuhi kualifikasi minimum pasar kerja masa depan. Lebih dari 85 juta jenis pekerjaan berpotensi tergantikan oleh otomasi, digitasi dan artificial intelligence (AI) yang akan berimplikasi pada perubahan orientasi perusahaan dalam kualifikasi tenaga kerja yang dibutuhkan (World Economic Forum, 2020) namun membuka peluang bagi 97 juta jenis pekerjaan baru yang mengkolaborasikan kemampuan SDM dan teknologi atau batuan komputer dalam fungsi administratif dan tugas-tugas rutin lainnya (Brownell dan Leko, 2018). Peluncuran program BLK Komunitas menjadi salah satu wujud konkrit leverage yang diupayakan pemerintah sebagai bentuk intervensi, diantaranya dengan pembangunan 1000 lembaga atau fasilitas pelatihan yang diperuntukkan untuk pelatihan vokasi di lembaga-lembaga keagamaan seperti pondok pesantren, seminari, dhammasekha, pasraman, dan komunitas lainnya dengan fokus meningkatakan kapabilitas siswa sesuai dengan kebutuhan dunia kerja, serta dukungan untuk minat berwirausaha (Biro Humas Kemnaker, 2020).

\section{KESIMPULAN}

Social Responsibility dalam rangka mempersiapkan modal manusia masa depan yang unggul dan berdaya saing menjadi titik temu dalam mewujudkan sebuah modal sosial lintas sektor. Pendidikan sebagai salah satu indikator utama pembangunan manusia di setiap negara diharapkan dapat cepat beradaptasi dengan seluruh dinamika yang ada termasuk dalam transformasi pembelajaran di era pandemi covid 19 maupun setelahnya. Dalam kaitannya dengan teori human capital, SDM berperan strategis dalam pendapatan nasional, dimana teknologi digital dapat menjadi jalan memperluas kesempatan peningkatan pendapatan angkatan kerja saat memasuki dunia kerja, dan 
kesempatan pula bagi anak anak untuk mempersiapkan masa depan mereka (UNICEF, 2018).

Hybrid atau blended learning diproyeksikan menjadi alternatif learning delivery model masa depan yang diyakini mampu lebih mengoptimalkan potensi peserta didik untuk dapat lebih resilience dan mandiri menggunakan kemampuan HOTS, sehingga menjadikan mereka mampu untuk memberikan nilai-nilai positif di lingkungan sekitar, serta secara luas memberikan dampak bagi kemajuan bangsa dan negara. Pemanfaatan TIK dalam proses pembelajaran telah secara nyata meningkatkan kualitas pendidikan, memperdalam keterampilan, memotivasi dan mengoptimalkan kompetansi yang dimiliki siswa (Noor-Ul-Amin 2013) yang diantaranya bergantung pada kebijakan yang fokus pada peningkatan kompetensi digital pedagogy guru - guru (Ratheeswari, 2018) intergroup connection, sinergitas kebijakan lintas institusional, termasuk memperluas kesempatan mendapatkan kesetaraan akses pembelajaran (OECD, 2020).

Akselarasi transformasi pendidikan dimasa pandemi covid 19 menjelaskan bahwa masih banyak negara termasuk Indonesia secara faktual masih membutuhkan kerja keras untuk mewujudkan ekosistem yang kondusif bagi pengembangan pembelajaran berbasis digital. Ketimpangan akses dan konektivitas listrik serta jaringan internet, disparitas mutu SDM (tenaga pendidik), sarana prasarana penunjang pendidikan, tingkat kesejahteraan keluarga yang terjadi antar satu provinsi dengan provinsi lainnya, sebagaimana data nasional menunjukkan bahwa wilayah Indonesia bagian timur khususnya Papua masih memerlukan banyak intervensi dan inovasi. Upaya peningkatan kualitas hidup masyarakat Papua dan Papua Barat melalui pengelolaan Dana Otonomi Khusus nyatanya belum dapat secara signifikan mengatasi kompleksitas permasalahan sosial masyarakat disana, yang diantaranya disebabkan karena belum dikelola secara memadai dan berujung dengan sejumlah penyimpangan yang sangat mempengaruhi efektivitas pencapaian tujuan dari alokasi anggaran tersebut (BPK RI, 2021). Intervensi pemerintah pusat yang didukung oleh sektor swasta baik pada pembangunan infrastruktur pendidikan maupun penyediaan bahan ajar berbasis digital yang adaptif akan membawa sebuah keniscayaan bagi daerah-daerah yang masih tertinggal seperti halnya Papua.

Tujuan pembelajaran akan semakin optimal dengan adanya interkoneksi informasi global dalam proses belajar yang diperoleh melalui jaringan internet. Melalui 
pendekatan evaluasi Developmental yang dikembangan Michael Quinn Patton, penelitian ini mengelaborasikan sejumlah leverage points (daya ungkit) yang dapat timbul dari adanya kolaborasi lintas institusi dengan kompetensi dan kapasitasnya masing-masing dalam kerangka dan tujuan yang sama yaitu percepatan digitalisasi dalam pembelajaran yang menjadi wujud konkrit modal sosial pada transformasi pendidikan di tanah air.

Penelitian ini setidaknya mengidentifikasi 6 komponen utama (pada gambar 6) yang krusial untuk dipersiapkan dalam mewujudukan Universal Digitation in Learning di tanah air yaitu:

1. L1: Kemitraan pemerintah dan sektor swasta (provider perangkat keras dan lunak) dalam pembangunan infrastruktur digital, serta pemberian kursus-kursus atau pelatihan teknis maupun pendampingan kepada sekolah dan tenaga pendidik, bertujuan untuk meningkatkan kemampuan dasar operasionalisasi perangkat digital, serta dalam rancangan kelas virtual yang menarik dan interaktif bagi siswa;

2. L2: Kontribusi public-private partnership dalam peningkatan kompetensi guru untuk skema pembelajaran dan kemampuan mengajar berbasis digital (digital pedagogic teaching). Penting bagi seluruh pihak untuk menyadari beratnya beban guru-guru dalam mengadaptasi model pengajaran berbasis digital. Kemampuan menghadirkan inovasi pembelajaran maupun komunikasi yang baik menjadi kunci keberhasilan pembelajaran jarak jauh dimasa pandemi (ILO, 2021). Hal ini yang perlu menjadi concern pemerintah dan sektor swasta, yang kemudian meningkatkan peran lembaga-lembaga training profesional untuk penguatan kompetensi mengajar tenaga pendidik;

3. L3: Kolaborasi pengembangan materi ajar. Konten atau materi ajar yang handal dapat meningkatkan kualitas pengetahuan, keterampilan komputasi maupun digital literacy peserta didik, serta diharapkan dapat memberikan peningkatan pada capaian assessment PISA mendatang. Upaya ini diharapkan tidak hanya berorientasi pada penciptaan konten-konten belajar yang berkualitas dan terstandard lokal, namun dapat setara atau terstandar global, sehingga kemitraan pemerintah pusat dengan sejumlah negara maupun dengan institusi pengembang konten belajar berskala internasional dapat menjadi satu langkah solutif. Hal lain yang dibutuhkan adalah ketersediaan bahan ajar yang affordable bagi semua kalangan, sehingga perlu 
strategi khusus agar bahan ajar tersebut tidak berbayar dan siap pakai tanpa membebani satuan pendidikan, guru maupun orang tua;

4. L4: Dukungan Dunia Usaha dan Industri pada dunia pendidikan dapat meningkatkan kompetensi dasar angkatan kerja. Pengembangan aplikasi/ platform belajar yang aplikatif bagi siswa, yang diperkenalkan sejak jenjang sekolah menengah, disertai penyediaan tools penunjang pembelajaran seperti projektor interaktif untuk guru, akan semakin meningkatkan kualitas pembelajaran virtual. Penggunaan aplikasi atau software (yang umum digunakan dalam dunia kerja seperti program pyton dan sebagainya) kedalam aktivitas belajar akan sangat bermanfaat bagi peserta didik ketika kelak masuk kedalam dunia kerja, sehingga diharapkan akan ada sebuah terobosan dalam bentuk pemutakhiran kurikulum pada jenjang pendidikan menengah yang bersifat link and match dengan kebutuhan pasar tenaga kerja;

5. L5: Fasilitasi peningkatan kompetensi peserta didik di jenjang pendidikan tinggi yang berorientasi pada pemenuhan kompetensi dasar di dunia kerja. Hal tersebut diharapkan dapat ditindaklanjuti dalam bentuk kesepakatan bersama antara pemerintah pusat (lintas kementerian) bersama-sama dengan sektor industri agar angkatan kerja masa depan dapat dengan mudah terserap di dunia kerja;

6. L6; Kolaborasi/ kemitraan DU/ DI dan pemerintah dalam upaya percepatan transformasi pembelajaran berbasis digital, serta komitmen sektor swasta dalam memperkuat fungsi CSR untuk peningkatan kualitas pendidikan.

Pembangunan sumber daya manusia pada sektor pendidikan merupakan pintu masuk menuju masyarakat yang berdaya saing dan peradaban yang lebih maju. Sinergitas pemerintah pusat dan daerah dalam berbagi peran dan tanggung jawab secara proporsional yang ditunjang oleh dukungan dari sektor swasta termasuk organisasiorganisasi inpedenden yang memiliki concern yang sama, akan membentuk sebuah modal sosial yang kokoh dan memberikan nilai manfaat bagi masyarakat secara luas, khususnya pada pemerataan akses dan kualitas pendidikan serta penyiapan angkatan kerja dan SDM yang unggul dan berdaya saing di kemudian hari. 


\section{DAFTAR PUSTAKA}

Abrar ul Haq, Muhammad, Farheen Akram, dan Rana Muhammad Adeel Farooq. 2015. "The Impact of Social Capital on Educational Attainment: Evidence from Rural Areas of Pakistan." Research on humanities and Social Sciences 5(13):95-102.

Anon. 2020. "World Bank." The Promise of Education in Indonesia.

Anon. 2021. "APBN 2021 Dukung Pengembangan TIK Akselerasi Transformasi Ekonomi Menuju Indonesia Maju.” (November 2020):3846663.

Boeck, Thilo, dan Jennie Fleming. 2005. "Social Policy - A Help or a Hindrance to Social Capital?" Social Policy and Society 4(3):259-70.

BPK RI. 2021. Pendapat BPK dalam Pengelolaan Dana Otonomi Khusus pada Provinsi Papua dan Papua Barat 2021.

Brownell, Mary T., dan Melinda M. Leko. 2018. "Advancing Coherent Theories of Change in Special Education Teacher Education Research: A Response to the Special Issue on the Science of Teacher Professional Development."

Dikti, Ditjen. 2020. Panduan Penyusunan Kurikulum Pendidikan Tinggi.

DiStefano, Christine, dan Grant B. Morgan. 2010. "Evaluation of the BESS TRS-CA Using the Rasch Rating Scale Model." School Psychology Quarterly 25(4):20212.

Fadhil, Mhd, Al Hakim, Sariyatun Sariyatun, dan Sudiyanto Sudiyanto. 2018. "International Journal of Multicultural and Multireligious Understanding Constructing Student 's Critical Thinking Skill Through Discovery Learning Model and Contextual Teaching and Learning Model as Solution of Problems in Learning History.” 175-83.

Fathy, Rusydan. 2019a. "Modal Sosial: Konsep, Inklusifitas Dan Pemberdayaan Masyarakat." Sosioglobal : Jurnal Pemikiran dan Penelitian Sosiologi 3(2):35.

Fathy, Rusydan. 2019b. "Modal Sosial: Konsep, Inklusivitas dan Pemberdayaan Masyarakat." Jurnal Pemikiran Sosiologi 6(1):1.

Guijt, Irene, Cecile Kusters, Hotze Lont, dan Irene Visser. 2012. "Developmental Evaluation: Applying complexity concepts to enhance innovation and use Report from an Expert Seminar with Dr. Michael Quinn Patton.” (June 2018).

Howell. n.d. "Chapter 1 What is a digital pedagogy and why do we need one ? Oxford University Press Sample Chapter.” 3-17.

ILO. 2021. Skills development in the time of COVID-19:

Imandoust, Sadegh Bafandeh. 2011. "Relationship Between Education and Dementia." International Journal of Humanities and Social Science 1(12):52-57.

Jumirah, Heni Wahyuni. 2018. "The Effect of Social Capital on Workforce Productivity." Journal of Indonesian Economy and Business 33(Number I):65-76.

Kecerdasan, Inventori, dan Pelbagai Ikep. n.d. Katalog BPS 4301002.

Kemendikbud. 2017. "Gerakan Penguatan Pendidikan Karakter (PPK) [Infographics of 
the Strengthening Character Education Movement]." Indonesian Ministry of Education and Culture 1-10.

King, Jean. 2006. "Evaluation [ Theory ] Approaches and Models."

Koleros, Andrew, Dee Jupp, Sean Kirwan, Meeta S. Pradhan, Pushkar K. Pradhan, David Seddon, dan Ansu Tumbahangfe. 2016. "Methodological Considerations in Evaluating Long-Term Systems Change : A Case Study From Eastern Nepal."

Lang, Robert E., dan Steven P. Hornburg. 1998. "What is social capital and why is it important to public policy?" Housing Policy Debate 9(1):1-16.

Leeuw, Frans L., dan Stewart I. Donaldson. 2015. "Theory in evaluation: Reducing confusion and encouraging debate.” Evaluation 21(4):467-80.

Louie, Josephine, Christopher Rhoads, dan June Mark. 2016. "Challenges to Using the Regression Discontinuity Design in Educational Evaluations : Lessons From the Transition to Algebra Study."

McGrath, Simon. 2010. "The role of education in development: An educationalist's response to some recent work in development economics." Comparative Education 46(2):237-53.

Noor-Ul-Amin, Syed. 2013. "An Effective use of ICT for Education and Learning by Drawing on Worldwide Knowledge, Research, and Experience : ICT as a Change Agent for Education." Department Of Education University of Kashmir 1(1):1-13.

OECD. 2019a. "ENVISIONING THE FUTURE Trends , data and drawings.” 20.

OECD. 2019b. "OECD learning compass 2030: In brief." OECD Future of Education and Skills 2030.

OECD. 2020. PISA 2018 Global competences. Vol. I.

OECD. 2021. "OECD Economic Surveys.” OECD Survey (March).

Patton, Michael Quinn. 1994. "Developmental Evaluation." American Journal of Evaluation 15(3):311-19.

Patuelli, Roberto, dan Marco Savioli. 1920. "Social capital, institutions and policy making."

Ratheeswari, K. 2018. "Information Communication Technology in Education." Journal of Applied and Advanced Research 3(S1):45.

Sailin, Siti Nazuar, dan Noor Aida Mahmor. 2018. "Improving student teachers' digital pedagogy through meaningful learning activities." Malaysian Journal of Learning and Instruction 15(2):143-73.

Schleicher, Andreas. 2019. "PISA 2018 insights and interpretations." OECD Publishing 64.

Studi, Program, dan Teknik Komputer. 2020. "Dokumen rencana strategis.” 1-2.

Suharto, Edi. 2008. "Modal Sosial dan Kebijakan Publik." 1-16.

Syahra, Rusydi. 2003. "Modal sosial: Konsep dan aplikasi." Jurnal Masyarakat dan Budaya 5(1):1-22. 
UNICEF. 2018. "Raising Learning Outcomes: the opportunities and challenges of ICT for learning." (September):1-8.

Woolhouse, John, dan Jill Cramphorn. 1999. "The Role of Education in Economic Development." Industry and Higher Education 13(3):169-75.

World Bank. 2020. "Edtech in Indonesia - Ready for Take-Off?” (May):1-84.

World Economic Forum. 2020. "The Future of Jobs Report 2020 | World Economic Forum." Research Report (October):1163. 